\title{
Levalbuterol Hydrochloride
}

National Cancer Institute

\section{Source}

National Cancer Institute. Levalbuterol Hydrochloride. NCI Thesaurus. Code C47580.

The hydrochloride salt form of levalbuterol, a relatively selective sympathomimetic beta2 adrenergic receptor agonist with bronchodilator activity. Levalbuterol hydrochloride binds to beta-2 adrenergic receptors in bronchial smooth muscle and activates intracellular adenyl cyclase, thereby increasing the production of cyclic-3', 5'-adenosine monophosphate (CAMP). Increased CAMP levels lead to the activation of protein kinase A, which inhibits the phosphorylation of myosin and lowers intracellular ionic calcium concentrations, resulting in relaxation of bronchial smooth muscles. The increased cyclic AMP concentrations also inhibit the release of inflammatory mediators from mast cells. 